\title{
Project to improve end-of-life support in Western Canada
}

Health Canada's new $\$ 4.3$ million Pallium Project (www .pallium.ca) aims to improve palliative care in rural Western and Northern Canada. With only about 20 specialized palliative care units in Canada, an estimated 240000 Canadians die each year without appropriate end-of-life support.

The 30-month Pallium Project, which was launched in December 2003, will provide educa- tion to family physicians, nurses, pharmacists and other health care professionals via teleconference, the Internet, toll-free phone lines and courses. Palliative care specialists will be available for telehealth case consultations.

"Many Canadian physicians and health professionals have not been trained in palliative pain and symptom management, or in grief and bereavement support," notes Dr. Jose Pereira, the project leader. Pallium will establish palliative care resource teams in every health region and is working with medical schools to improve palliative care curriculum.

Consultant Michael Aherne says the new federal compassionate leave benefit may drive demand for improved palliative care. "Consumers will be looking for professionals to direct them to better ... resources." Heather Kent, Vancouver

\section{Research Legislation}

\section{Embryonic stem cell research finally regulated}

Rapid advances in research into the pluripotent nature of stem cells derived from human embryos, including their potential use in treating degenerative conditions such as Parkinson's disease, Alzheimer's disease, heart failure, diabetes etc., have collided with opposing views regarding the morality of using human embryos for these purposes.

Federal funding for stem cell research has been on hold since 2002 while Parliament debated legislation, leaving frustrated researchers cooling their heels.

Ten years after a blue-chip committee recommended immediate regulation, the House of Commons finally passed Bill C13 in October. Renamed Bill C6, the Act Respecting Assisted Human Reproduction and Related Research was only recently approved by the Senate Committee on Social Affairs, Science and Technology, and went to Senate for final approval in early March.

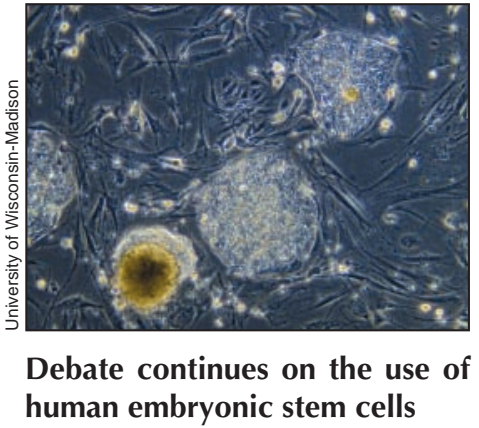

The Bill calls for the creation of the Assisted Human Reproductive Agency of Canada (AHRAC) to oversee all clinical and research activities in this area, including the granting of licences to clinicians and researchers involved in the use of in-vitro embryos.

Bill C-6 prohibits 10 activities, including creating a human clone, sale of sperm or ova and commercial surrogacy. Penalties defined in the Criminal Code include fines of up to $\$ 500000$ and imprisonment for up to 10 years.

The CMA has refused to endorse the Bill. Dr. Eugene Bereza, chair of the CMA ethics committee, said the criminal penalties are a mistake because the science will likely progress more quickly than legislators' ability to change the law. He recommends giving the power to stipulate and enforce permissible procedures to the AHRAC.

The Society of Obstetricians and Gynaecologists of Canada supported the Bill because it will regulate the rapidly growing field of in-vitro fertilization (and provide women with clinic performance data).

Despite these advances, researchers will still have limited access to stem cells. The Bill permits the use of stem cells obtained from discarded products of in-vitro fertilization (unused embryos), but it bans human cloning to obtain stem cells. This could be important because of the shortage of stem cells and the therapeutic advantages of using cloned cells. It is presumed that using cloned embryos, as was recently done in Korea (see page 1069), will eliminate the problem of immunological rejection.

Human cloning for research is permitted under laws passed in the UK and several European countries. In 2001, the US restricted federal funding for embryonic stem cell research to stem cell lines that were already in existence, but proscribed therapeutic cloning and research that required use of discarded human embryos. The US legislation left the private sector virtually unrestricted in the scope of its research. Several US universities, most recently Harvard, have launched appeals for private funding of stem cell research.

In Canada, Dr. Ronald Worton, scientific director of the Stem Cell Network (a branch of the Networks of Centres of Excellence), said his researchers have no plans to clone embryos, but "if there is evidence that cloned embryos are important" this information would be presented to Parliament when the Bill (if approved) comes up for obligatory Parliamentary review 3 years after it is passed. - Ben Hadaway, CMAJ 